\title{
KELIMPAHAN COPEPODA (ORDO: CALANOIDA) DI TELUK PEGAMETAN, BALI UTARA
}

\author{
Gede S. Sumiarsa*) dan Media Fitri Isma Nugraha*) \\ *) Balai Besar Riset Perikanan Budidaya Laut \\ Jl. Br. Gondol, Kec. Gerokgak, Kab. Buleleng, Singaraja - Bali 81101 \\ E-mail: gedess@hotmail.com \\ **) Loka Riset Budidaya Ikan Hias Air Tawar \\ Jl. Perikanan No. 13, Pancoran Mas, Depok 16436
}

Naskah diterima: 15 Oktober 2008; Diterima publikasi: 12 Januari 2009

\begin{abstract}
ABSTRAK
Pengamatan kelimpahan spesies copepoda, ordo Calanoida di Teluk Pegametan, Bali telah dilaksanakan pada bulan April 2007. Teluk Pegametan adalah salah satu wilayah yang potensial untuk budidaya laut yang terletak di bagian barat Laut Bali. Penelitian ini bertujuan untuk menginventarisasi spesies-spesies copepoda dari ordo Calanoida yang hidup di perairan Teluk Pegametan. Penelitian ini dilakukan pada 10 stasiun sampling dengan metode sampling secara horizontal pada permukaan laut. Plankton net berdiameter $31 \mathrm{~cm}$ dengan ukuran mesh $40 \mu \mathrm{m}$ ditarik sepanjang 10 meter dengan menggunakan speed boat di sekitar stasiun pengamatan. Sampel diawetkan dengan formalin $4 \%$ untuk diidentifikasi. Dari hasil pengamatan di sepuluh stasiun terdapat 14 spesies copepoda ordo Calanoida yaitu: Acrocalanus gracilis, Calanus minor, C. sinicus, C. tenuicornis, Centropoges abdominalis, Eucalanus attenuatus, Haloptilus longicornis, Lucicutia curta, L. flavicornis, Parvocalanus crassirostris, Pseudocalanus gracilis, Rinchalanus cornutus, Scolecithricella minor, dan Temora turbinata. Spesies dominan adalah Calanus sinicus dengan proporsi $65,6 \%$ dari jumlah individu yang dijumpai.
\end{abstract}

KATA KUNCI: Copepode, Calanoida, kelimpahan

ABSTRACT: The abundance of copepod species (Order: Calanoida) in Pegametan Bay, North Bali. By: Gede S.Sumiarsa and Media Fitri Isma Nugraha

Observation on the abundance of copepod species (order: Calanoida) in Pegametan Bay has been conducted in April 2007. Pegametan Bay is located on the North West of Bali and is one of several potential areas for mariculture. The purpose of this study was to find out the abundance of copepod (Order: Calanoida) in the bay. Research sampling was conducted in 10 sampling points where planktons were collected using plankton net of $40 \mathrm{\mu m}$ mesh size with diameter of $31 \mathrm{~cm}$ dragged horizontally on the sea water surface as far as $10 \mathrm{~m}$ each. Samples were preserved in $4 \%$ formalin for identification. There were 14 species of Calanoida copepod species found during the research: Acrocalanus gracilis, Calanus minor, C. sinicus, C. tenuicornis, Centropoges abdominalis, Eucalanus attenuatus, Haloptilus longicornis, Lucicutia curta, L. flavicornis, Parvocalanus crassirostris, Pseudocalanus gracilis, Rinchalanus cornutus, Scolecithricella minor, and Temora turbinata. Dominant species was Calanus sinicus constituting $65.8 \%$ of the total Calanoida abundance.

KEYWORDS: Calanoida, Copepods, identification 


\section{PENDAHULUAN}

Indonesia terdiri atas 18,306 pulau (Anonymous, 2008) dan hampir setiap pulau memiliki teluk. Teluk Pegametan adalah sebuah teluk yang terletak di bagian barat laut Pulau Bali yang terletak di Desa Sumberkima, Kecamatan Gerokgak, Kabupaten Buleleng dengan letak geografis di antara S: 9102541 , E: 235171 dan S: $9102541, \mathrm{E}: 237867$ dengan luas area sekitar 1,160 km² (Andriyanto et al., 2006). Teluk ini merupakan wilayah potensial bagi kegiatan budidaya laut di mana $88 \%$ mata pencaharian masyarakat di sekitarnya adalah nelayan ikan hias, $6 \%$ nelayan ikan konsumsi, dan masing-masing 3\% adalah nelayan pembudidaya rumput laut dan pembudidaya keramba jaring apung (kerapu dan bandeng) (Andriyanto et al., 2006). Sedangkan sumberdaya perairan yang terdapat di teluk ini adalah sumberdaya ikan, udang-udangan, moluska, rumput laut, bakau, dan terumbu karang yang tentunya didukung oleh kesuburan perairan tersebut. Salah satu indikator untuk mengetahui tingkat kesuburan dari suatu perairan adalah berlimpahnya jumlah plankton baik fitoplankton maupun zooplankton (Hutabarat \& Evans, 1985).

Copepoda merupakan salah satu jenis zooplankton yang banyak terdapat di perairan laut maupun air tawar dan populasi copepoda biasanya terdiri atas $50 \%-80 \%$ dari jumlah total zooplankton yang memangsa lebih banyak diatom dibandingkan zooplankton jenis lain sehingga merupakan salah satu komponen penting dalam rantai makanan (Nybakken, 1992). Dalam siklus rantai makanan, mereka terletak antara produsen primer seperti diatom dan ikan kecil seperti teri dan tembang (Romimohtarto \& Juwana, 2001). Copepoda dapat di golongkan dalam empat ordo yaitu Calanoida, Cyclopoida, Harpacticoida, dan Monstrillidae (Yamaji, 1986). Di antara keempat ordo copepoda, Calanoida termasuk spesies yang berperan penting dalam rantai makanan di laut karena jumlahnya berlimpah, kosmopolit, distribusi merata sehingga menjadikannya sebagai salah satu rantai makanan utama bagi binatang laut. Calanoida terdiri atas 43 famili dengan sekitar 2.000 spesies (Boltovskoy et al., 1999). Di perairan laut, Calanoida sangat penting mulai bagi protozoa yang berukuran sangat kecil sampai ikan besar dan bahkan bagi beberapa jenis ikan paus. Pada banyak jenis ikan komersial dan non komersial dan juga krustasea menjadikan copepoda sebagai sumber makanan alami utama selama tahap larva (Bradford-Grieve, 2002).

Secara morfologis singkat copepoda ordo Calanoida dapat dijelaskan yaitu bagian tubuh copepoda Calanoida terdiri atas dua bagian yaitu prosome dan urasome dengan bagian utama terjadi antara lima pedigerous dan genital somitel (gymnoplean position). Urasome terdiri atas empat somite bebas pada betina dan lima somite bebas pada jantan. Pada penyatuan antara somite ini diakhiri dengan caudal rami (duri ekor) (Williamson \& Reid, 2001). Pentingnya penelitian kelimpahan ordo Calanoida ini untuk budidaya adalah untuk mengetahui spesies Calanoida yang berlimpah di perairan Teluk Pegametan yang diharapkan dapat dibudidayakan sebagai pakan alami pengganti artemia dan rotifer bagi larva ikan laut. Tujuan dari penelitian ini adalah untuk menginventarisasi spesies-spesies copepoda dari ordo Calanoida yang hidup di perairan Teluk Pegametan.

\section{BAHAN DAN METODE}

\section{Metode Penelitian}

\section{Waktu dan Lokasi}

Penelitian ini dilakukan pada bulan April 2007 di Teluk Pegametan, Desa Sumberkima, Kecamatan Gerokgak, Kabupaten Buleleng, Bali Utara (Gambar 1). Peta dibuat dari citra IKONOS dengan titik (stasiun) sampling ditentukan berdasarkan metode purposive sampling.

Sampling copepoda dilakukan secara horizontal pada permukaan laut pada kedalaman rata-rata $0,5 \mathrm{~m}$ menggunakan plankton net berdiameter $31 \mathrm{~cm}$ dan dengan ukuran mesh $40 \mu \mathrm{m}$. Plankton net ditarik sepanjang 10 meter dengan menggunakan speed boat di sekitar stasiun pengamatan. Jumlah volume air laut yang terambil dihitung dengan menggunakan rumus:

$$
\left(\pi r^{2} L\right)
$$

di mana:

$\pi=3,14$

$r=$ radius plankton net

$\mathrm{L}=$ jarak tarikan plankton net

Total volume air laut yang terambil setiap sampel adalah $754 \mathrm{~L}$, disaring menjadi $50 \mathrm{~mL}$, sampel diawetkan dengan formalin $4 \%$ dan 


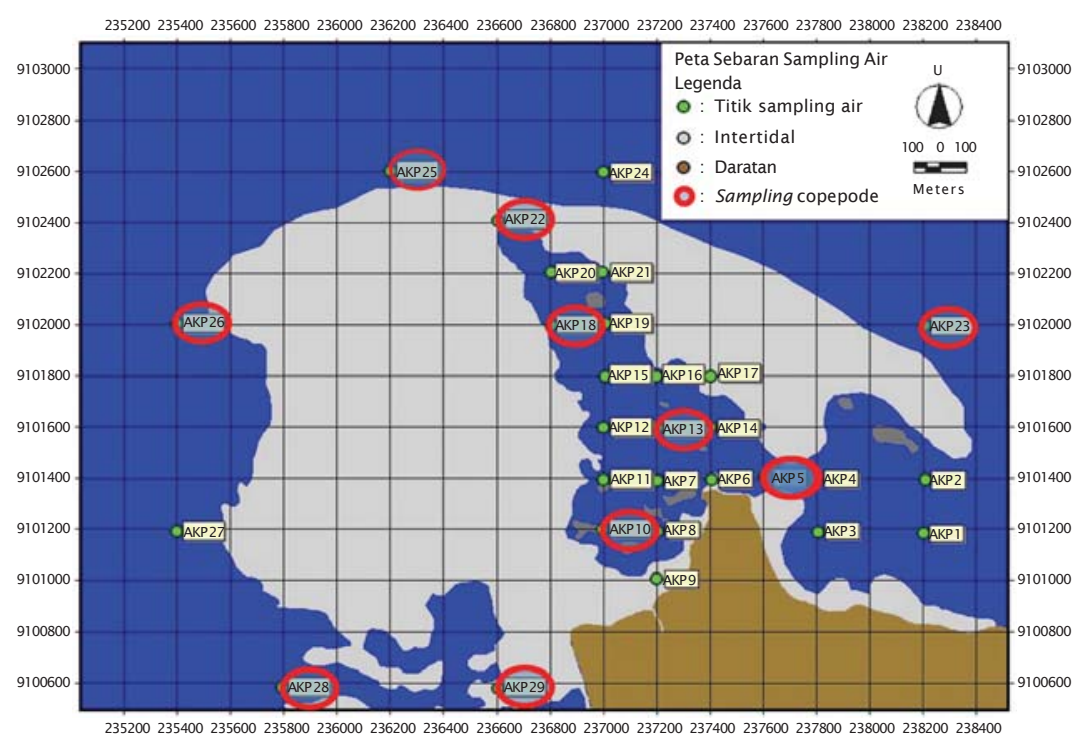

Gambar 1. Lokasi sampling copepoda di Teluk Pegametan (lingkaran merah)

Figure 1. Sampling sites of copepods in Pegametan Bay (red circle)

selanjutnya dilakukan identifikasi copepoda ordo Calanoida di laboratorium. Penentuan spesies copepoda berdasarkan Yamaji (1986), di mana pengelompokan dilakukan sampai tingkat ordo Calanoida. Copepoda sangat jelas terlihat perbedaanya di tingkat ordo dengan membedakan bentuk tubuh. Di mana bentuk tubuh copepoda ordo Calanoida lebih gemuk, panjang, dan besar dengan bagian ekor pendek. Setelah diseleksi copepoda yang tergolong Calanoida selanjutnya dilakukan identifikasi berdasarkan spesies dengan menggunakan buku penuntun Yamaji (1986). Setelah data spesies copepoda hanya ordo Calanoida didapatkan dilakukan analisis koordinat utama/PCA (Principle Component

Tabel 1. Parameter fisika perairan Teluk Pegametan pada saat sampling

Table 1. Measured physical parameters in sampling sites

\begin{tabular}{ccccccccc}
\hline \multirow{2}{*}{$\begin{array}{c}\text { Lokasi } \\
\text { Sites }\end{array}$} & $\begin{array}{c}\text { Koordinat * } \\
\text { Coordinate }\end{array}$ & $\begin{array}{c}\text { Kedalaman } \\
\text { Depth } \\
\mathbf{( m )}\end{array}$ & $\begin{array}{c}\text { Kecerahan } \\
\text { Water } \\
\text { Clarity } \\
(\mathbf{m})\end{array}$ & $\begin{array}{c}\text { Suhu } \\
\text { Temperature } \\
\left({ }^{\circ} \mathbf{C}\right)\end{array}$ & $\begin{array}{c}\text { Arah } \\
\text { angin } \\
\text { Wind } \\
\text { direction }\end{array}$ & $\begin{array}{c}\text { A rus } \\
\text { Water } \\
\text { Current }\end{array}$ & $\begin{array}{c}\text { Salinitas } \\
\text { Salinity }\end{array}$ \\
\hline AKP 5 & 9101426 & 237589 & 17.4 & 5 & 28.7 & Timur & Timur & 35 \\
AKP 10 & 9101236 & 237067 & 13.5 & 4 & 29 & Timur & Timur & 34 \\
AKP 13 & 9101726 & 237096 & 15 & 4 & 28 & Utara & Timur & 34 \\
AKP 18 & 9102200 & 236695 & 5.6 & 5 & 27.5 & Utara & Timur & 33 \\
AKP 22 & 9102410 & 236426 & 10.6 & 4 & 27 & Barat & Timur & 34 \\
AKP 23 & 9102128 & 238157 & 27.6 & 11 & 29 & Timur & Timur & 34 \\
AKP 25 & 9102620 & 236500 & 42.7 & 9 & 28 & Selatan & Timur & 35 \\
AKP 26 & 9102178 & 235421 & 24.8 & 7 & 28 & Selatan & Timur & 33 \\
AKP 28 & 9100566 & 236131 & 12.6 & 4 & 29 & Timur & Timur & 33 \\
AKP 29 & 9100420 & 236561 & 8.3 & 3 & 29 & Timur & Timur & 33 \\
\hline
\end{tabular}

Keterangan (Remark): * S50 UTM WGS 84 coordinate system 
Tabel 2. Parameter kimia permukaan air laut pada setiap lokasi pengamatan

Table 2. Chemical parameters of sea water surface on sampling sites

\begin{tabular}{ccccccc}
\hline \multirow{2}{*}{$\begin{array}{c}\text { Stasiun } \\
\text { Stations }\end{array}$} & \multicolumn{5}{c}{ Parameter kimia (Chemical parameters) } \\
\cline { 2 - 7 } & $\mathbf{p H}$ & $\mathbf{P O}_{4}{ }^{2-}$ & $\mathrm{NH}_{3}$ & $\mathrm{NO}_{2}{ }^{-}$ & NO $^{2-}$ & TSS \\
\hline AKP 5 & 8.3 & 0.021 & 0.014 & 0.005 & 0.014 & 0.026 \\
AKP 10 & 8.3 & 0.031 & 0.015 & 0.007 & 0.048 & 0.035 \\
AKP 13 & 8.3 & 0.021 & 0.008 & 0.010 & 0.033 & 0.037 \\
AKP 18 & 8.3 & 0.017 & 0.008 & 0.008 & 0.045 & 0.045 \\
AKP 22 & 8.3 & 0.017 & 0.011 & 0.009 & 0.034 & 0.030 \\
AKP 23 & 8.3 & 0.024 & 0.015 & 0.023 & 0.019 & 0.021 \\
AKP 25 & 8.3 & 0.031 & 0.011 & 0.009 & 0.013 & 0.023 \\
AKP 26 & 8.3 & 0.017 & 0.011 & 0.019 & 0.033 & 0.021 \\
AKP 28 & 8.3 & 0.017 & 0.013 & 0.014 & 0.094 & 0.022 \\
AKP 29 & 8.3 & 0.042 & 0.013 & 0.009 & 0.034 & 0.035 \\
\hline
\end{tabular}

Analysis) dengan menggunakan software NTSYS PC 2.02 untuk melihat hubungan sebaran dari masing-masing spesies copepoda ordo Calanoida di Teluk Pegametan.

\section{HASIL DAN BAHASAN}

Pengamatan fisik dari kondisi horizontal perairan Gondol saat penelitian dilakukan disajikan pada Tabel 1 .

Dari Tabel 1 terlihat bahwa kedalaman total kesepuluh stasiun sampling di Teluk
Pegametan tidak sama berkisar antara 8,342,7 meter. Stasiun sampling AKP 5, 10, 13, 18 , dan 22 terletak di antara daerah intertidal dengan kedalaman tidak lebih dari 20 meter. Arah angin beragam dari semua penjuru mata angin namun dominan arah Timur dan Selatan sedangkan arah arus dari timur dan salinitas air laut antara 33-35 ppt. Variabel kimia yang diukur adalah $\mathrm{pH}, \mathrm{PO}_{4}{ }^{2-}, \mathrm{NH}_{3}, \mathrm{NO}_{2}, \mathrm{NO}_{3}{ }^{2-}$, dan Total Soluble Solid (TSS). Hasil analisis beberapa variabel kimia masing-masing stasiun pengamatan dicantumkan pada Tabel 2 .

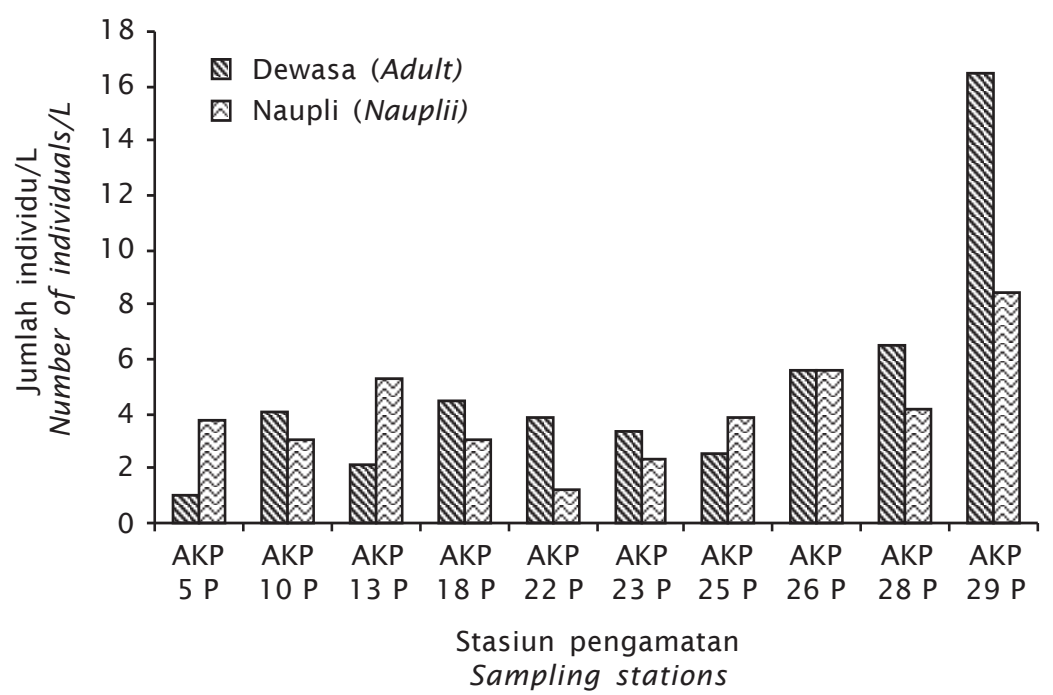

Gambar 2. Populasi copepoda di Teluk Pegametan

Figure 2. Populations of copepods in Pegametan Bay 
Populasi total copepoda (nauplii dan dewasa) dihitung secara keseluruhan tanpa membedakan ordo copepoda dicantumkan pada Gambar 2.

Dari Gambar 2 terlihat bahwa baik nauplii maupun copepoda dewasa dijumpai pada semua stasiun pengamatan dan populasi copepoda dewasa dan nauplii copepoda pada setiap stasiun pengamatan beragam. Jumlah nauplii copepoda paling sedikit dijumpai pada stasiun AKP 22 dan tertinggi dijumpai pada stasiun AKP 29 sedangkan jumlah copepoda dewasa paling sedikit dijumpai pada stasiun AKP 5 dan yang terbanyak pada stasiun AKP 29. Stasiun AKP 29 terletak paling dekat dengan pantai dengan kedalaman hanya sekitar 8,3 $\mathrm{m}$ dan kecerahan hanya $3 \mathrm{~m}$ yang nampaknya merupakan habitat terbaik bagi copepoda, sehingga kelimpahannya paling tinggi. Berbeda dengan stasiun AKP 5 walaupun juga cukup dekat dengan pantai tetapi memiliki kedalaman 17,4 m dengan kecerahan $5 \mathrm{~m}$ akan tetapi populasi copepoda di stasiun AKP 5 ini paling sedikit. Hal ini juga pernah dilaporkan oleh Belmonte et al. (2006) pada daerah Pollini National Park (Italia) terdapat perbedaan kedalaman antara daerah San Giargio dengan posisi 4005'24" N; $16^{\circ} 22^{\prime} 09^{\prime \prime S}$ dengan kedalaman $2 \mathrm{~m}$ dengan daerah Avena dengan posisi $40^{\circ} 03^{\prime} 00^{\prime \prime} \mathrm{N}$; $16^{\circ} 14^{\prime} 45^{\prime \prime S}$ dengan kedalaman $3 \mathrm{~m}$. Terdapat perbedaan jumlah populasi copepoda di mana pada San Giargio hanya ada 3 spesies copepoda sedangkan pada Avena terdapat 8 spesies copepoda. Dari laporan Belmonte et al. (2006) tersebut dapat dilihat bahwa perbedaan kedalaman $1 \mathrm{~m}$ saja mempengaruhi jumlah spesies yang mendiami lokasi/daerah tersebut.

Reid (1992) mengemukakan fenomena tentang sebaran copepoda berdasarkan posisi garis lintang di Amerika Utara adalah bahwa copepoda merupakan componen zooplankton dan di dominasi oleh 1 atau 2 spesies dari ordo Calanoida atau Cyclopoida. Di mana sebagian besar dalam keadaan normal tidak jelas pola sebarannya apabila dihubungkan dengan posisi garis lintang, akan tetapi beberapa spesies dari genus Conthocamptidae sebarannya berkorelasi dengan garis lintang. Distribusi dan kelimpahan copepoda juga dipengaruhi oleh $\mathrm{pH}$ air laut, akan tetapi efeknya berubah-rubah terhadap masingmasing spesies.
Pada penelitian yang dilakukan oleh Confer et al. (1983) pada 20 danau kecil di Amerika Serikat dengan range $\mathrm{pH}$ 4,5-7,2 dengan mengamati kelimpahan Mesocyclops edax dan Leptodioptomus minutus, dimana kedua spesies ini kelimpahan tinggi pada $\mathrm{pH}$ tinggi dan populasi juga berlimpah pada $\mathrm{pH}$ rendah. Jadi dapat dikatakan bahwa $\mathrm{pH}$ juga berpengaruh terhadap kelimpahan copepoda, akan tetapi efeknya berubah-rubah. Study yang sama juga dilakukan oleh Ramalingam \& Raghunathan, (1982) terhadap Epischura lascustris dan Cyclops scutifer hanya terdapat pada pH 5,3 keatas. Berbeda pada Mesocyclops leuckarty hasil bioassay memperlihatkan $100 \%$ kehidupan dalam 8,5 jam pada range $\mathrm{pH}<5$ atau $>9,2$.

Dari populasi total tesebut diidentifikasi spesies copepoda dari ordo Calanoida saja karena ordo ini bersifat pelagik, sebarannya merata di setiap kedalaman dan kosmopolit. Dari hasil identifikasi didapatkan bahwa di Teluk Pegametan terdapat 14 spesies Calanoida yaitu Acrocalanus gracilis, Calanus minor, C. sinicus, C. tenuicornis, Centropoges abdominalis, Eucalanus attenuatus, Haloptilus longicornis, Lucicutia curta, L. flavicornis, Parvocalanus crassirostris, Pseudocalanus gracilis, Rinchalanus cornutus, Scolecithricella minor, dan Temora turbinata. Keberadaan dari masing-masing spesies ini dapat dilihat pada Tabel 3.

Pada Tabel 3 terlihat bahwa terdapat dua spesies yang dominan yaitu Calanus sinicus dan C. minor. Spesies yang pertama (C. sinicus) tersebar merata pada setiap stasiun pengamatan baik stasiun pengamatan yang berada di wilayah intertidal (AKP 5, AKP 10, AKP 13, AKP 18, dan AKP 22) maupun di luar wilayah intertidal (AKP 23, AKP 25, AKP 26, AKP 28, AKP 29) sedangkan C. minor tersebar pada tujuh statsiun pengamatan yang umumnya terdapat di luar wilayah intertidal (AKP 23, AKP 26, AKP 28, dan AKP 29).

C. sinicus adalah copepoda yang penting dalam suatu ekologi perairan karena merupakan makanan komersial utama bagi beberapa jenis ikan dan larva ikan. Seperti pada perairan Laut China Timur, perairan bagian barat Laut Pacific (Jepang hingga Vietnam) (Sun \& Zhang, 2005). Di Teluk Pegametan, copepoda juga merupakan zooplankton yang dominan. Seperti yang dilaporkan oleh Burhanuddin \& Praseno (1982) dalam Merta (1995) yang 


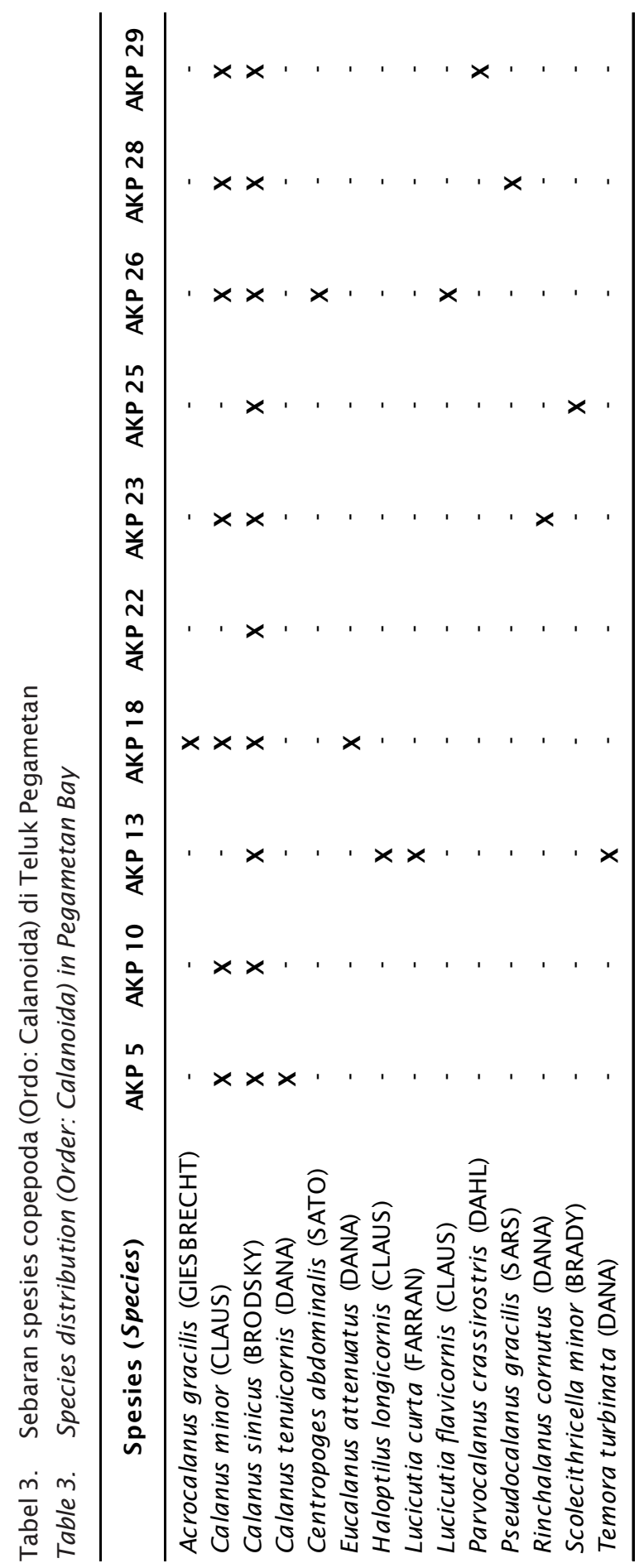


Tabel 4. Posisi relatif kelimpahan spesies copepoda (Ordo: Calanoida) dalam Principle Component Analysis

Table 4. Relative position of abundance of copepods species (Order: Calanoida) in Principle Component Analysis

\begin{tabular}{lccc}
\hline \multicolumn{1}{c}{ Spesies (Species) } & $\begin{array}{c}\text { Simbol } \\
\text { Symbols }\end{array}$ & $\begin{array}{c}\text { Dimensi 1 } \\
\text { Dimension 1 }\end{array}$ & $\begin{array}{c}\text { Dimensi 2 } \\
\text { Dimension 2 }\end{array}$ \\
\hline Acrocalanus gracilis (GIESBRECHT) & AG & 0.2579 & 0.1741 \\
Calanus minor (CLAUS) & CM & 0.7051 & 0.5775 \\
Calanus sinicus (BRODSKY) & CS & 0.5688 & 0.7914 \\
Calanus tenuicornis (DANA) & CT & -0.052 & -0.2449 \\
Centropoges abdominalis (SATO) & CA & 0.061 & -0.3933 \\
Eucalanus attenuatus (DANA) & EA & 0.2579 & 0.1741 \\
Haloptilus longicornis (CLAUS) & HL & -0.835 & 0.5232 \\
Lucicutia curta (FARRAN) & LC & -0.835 & 0.5232 \\
Lucicutia flavicornis (CLAUS) & LF & 0.061 & -0.3933 \\
Parvocalanus crassirostris (DAHL) & PC & 0.5612 & 0.6448 \\
Pseudocalanus gracilis (SARS) & PG & 0.1011 & -0.0153 \\
Rinchalanus cornutus (DANA) & RC & -0.0511 & -0.2734 \\
Scolecithricella minor (BRADY) & SM & -0.084 & -0.2903 \\
Temora turbinata (DANA) & TT & -0.835 & 0.5232 \\
\hline
\end{tabular}

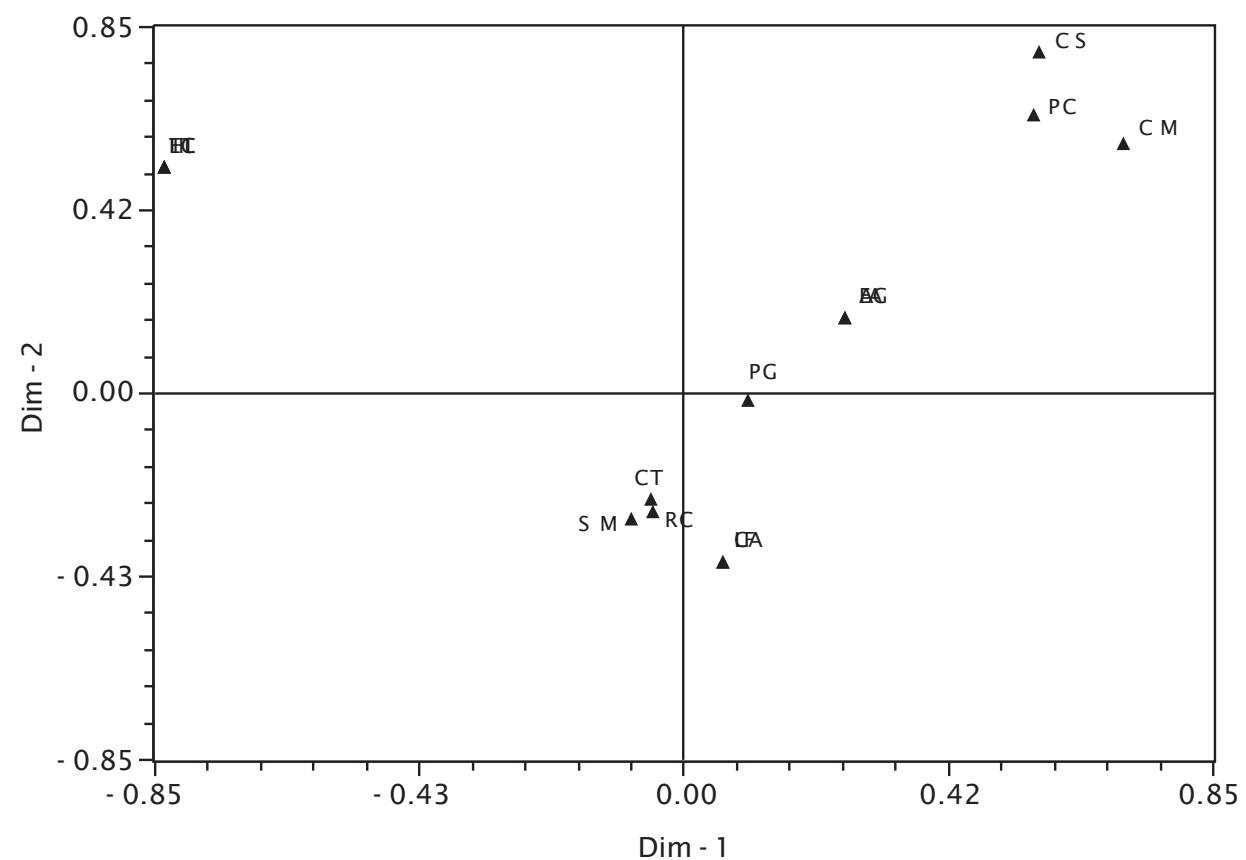

Gambar 3. Sebaran 14 spesies copepoda (Ordo: Calanoida) berdasarkan Principle Component Analysis di Teluk Pegametan

Figure 3. Distribution of 14 copepods species (Order: Calanoida) based on Principle Component Analysis in Pegametan Bay 
melakukan identifikasi isi perut ikan lemuru di Selat Bali, di sebelah selatan Ternate, Teluk Jakarta, Laut Jawa, dan di luar Jawa Tengah, mengatakan bahwa makanan utama ikan lemuru adalah zooplankton (91\%-96\%), fitoplankton $5 \%-10 \%$. Zooplankton yang paling banyak di konsumsi ikan lemuru adalah copepoda $(54 \%-$ 55\%), Decapoda 6,5\%-9,4\%.

Pada Tabel 3 terlihat juga bahwa spesies copepoda lainnya (Ordo: Calanoida) seperti Calanus tenuicornis, Centropoges abdominalis, Eucalanus attenuatus, Haloptilus longicornis, Lucicutia curta, L. flavicornis, Parvocalanus crassirostris, Pseudocalanus gracilis, Rinchalanus cornutus, Scolecithricella minor, dan Temora turbinata masing-masing hanya terdapat pada stasiun tertentu saja yang merupakan indikator bahwa spesies-spesies ini bukan merupakan spesies yang signifikan.

Berdasarkan Principle Component Analysis didapatkan posisi sebaran relatif kelimpahan copepoda berdasarkan analisis koordinat utama dalam dua dimensi dari masing-masing spesies copepoda di Teluk Pegametan yang dicantumkan pada Tabel 4.

Posisi relatif kelimpahan dari 14 spesies copepoda tersebut kemudian dicantumkan pada Gambar 3 di mana terdapat empat kelompok sebaran spesies copepoda di Teluk Pegametan.

Pada Gambar 3 terlihat pada kelompok 1 (kiri atas): Temora turbinata, Haloptilus longicornis, dan Lucicutia curta berhimpit karena memiliki nilai jumlah populasi yang sama pada setiap stasiun sampling. Demikian pula Acrocalanus gracilis dan Eucalanus attenuatus berhimpitan karena dalam posisi yang sama dalam kelompok 2 (kanan atas). Pada kelompok 2 juga tedapat spesies Calanus minor, Calanus sinicus, dan Parvocalanus crassirostris yang terletak terpisah satu sama lain. Spesies Centropoges abdominalis dan Lucicutia flavicornis juga berhimpitan yang terdapat pada kelompok 3 (kanan bawah) dan dalam kelompok ini juga terdapat Pseudocalanus gracilis yang tidak berhimpitan dengan spesies lainnya. Berbeda dengan Calanus tenuicornis, Scolecithricella minor, dan Rinchalanus cornutus yang berdekatan satu sama lain dan berada dalam kelompok 4 (kiri bawah). Spesies yang berhimpitan satu sama lain dalam koordinat Principle Component Analysis sebarannya hampir merata di setiap stasiun pengamatan. Seperti $C$. sinicus yang dijumpai pada setiap stasiun pengamatan sehingga dapat simpulkan bahwa $C$. sinicus tersebar merata di perairan Teluk Pegametan.

Dari hasil penelitian Calanoida yang potensial untuk di kultur secara massal di dalam bak pemeliharaan sebagai pakan alami larva ikan adalah Calanus sinicus. Spesies ini selalu terdapat di setiap stasiun pengamatan. Stasiun pengamataan yang kaya akan Calanoida adalah AKP 29 P, sehingga dapat dijadikan daerah acuan untuk pencarian copepoda ordo Calanoida.

\section{KESIMPULAN}

Dijumpai 14 spesies ordo Calanoida yang hidup di Teluk Pegametan yaitu: Acrocalanus gracilis, Calanus minor, $C$. sinicus, $C$. tenuicornis, Centropoges abdominalis, Eucalanus attenuatus, Haloptilus longicornis, Lucicutia curta, L. flavicornis, Parvocalanus crassirostris, Pseudocalanus gracilis, Rinchalanus cornutus, Scolecithricella minor, dan Temora turbinata. Populasi copepoda tertinggi terdapat pada stasiun AKP 29 dengan kedalaman 8,3 meter dan kecerahan sekitar 3 meter. Calanus sinicus merupakan spesies yang banyak dan tersebar merata pada setiap stasiun pengamatan.

\section{DAFTAR ACUAN}

Andriyanto,W., Hanafi, A. , Syahidah, D., Hakim, A.R., Sudarsono, \& Saraswati, W. 2006. Fasilitasi Informasi Sumberdaya Pesisir dan Laut untuk Menunjang Upaya Pengelolaan Berbasis Masyarakat Pesisir Teluk Sumberkima Bali Barat. Prosiding Seminar Nasional Tahunan III. Hasil Penelitian Perikanan dan Kelautan. Yogyakarta, 27 Juli, hlm. 1-11.

Anonymous. 2008. (http://id.wikipedia.org/ wiki/daftar_pulau_di_indonesia). Dilihat tanggal 3 February 2008).

Belmonte, G, Alfonso, G., \& Moscatello, S. 2006. Copepod fauna (Calanoida and Cyclopoida) in small ponds off the pollino National Park (south Italy), with notes on seasonality and biometry of species. J. Limnol., 65(2): 107113.

Boltovskoy, D., Gibbons, M.J., Hutchings, L., \& Binet, D. 1999. General biological features of the South Atlantic. In Boltovskoy, D. (Ed.). Zooplankton of the South Atlantic. Backhuys Publishers, Leiden, 1,706 pp.

Bradford. J.M-Grieve. 2002. Dalam http:// www.crustacea.net/crustece/calanoida/ index.htm. (Dilihat tanggal 10 Juni 2007). 
Confer, J.L., Kaaret,T. \& Likens, G.E. 1983. Zooplankton diversity and biomass in recently acidified lakes. Canadian Journal of Fisheries and Aquatic Science, 40: 36-42.

Hutabarat, S. \& Evans, S.M. 1985. Kunci Identifikasi Plankton. Penerbit Universitas Indonesia, $97 \mathrm{hlm}$.

Merta, I G.S. 1995. Review of the lemuru fishery in the Bali Strait. Pelfish. Jakarta. Report on the "Biodynex" Seminar, Biology, Dinamic and exploitation of the small pelagic fishes in the Java Sea. IARD Journal, 17(4): 71-75.

Nybakken, J.W. 1992. Biologi laut suatu pendekatan ekologis. Eidman, H.M., Koesoebiono, Bengen, D.G., Hutomo, M., Sukardjo, S. (Penerjemah). Terjemahan dari: Marine Biology and Ecological Approach. P.T. Gramedia, $268 \mathrm{hlm}$.

Ramalingam, K. \& Raghunathan, M.B. 1982. A study on the $\mathrm{pH}$ tolerance and survival of a cyclopoid copepod Mesocyclops leucarti (Claus). Comparative Physiology and Ecology, 7: 188-190.
Reid, J.W. 1992. Taxonomic problems: A serious impediment to groundwater ecological research in North America. In Stanford, J.A., Simons, J.J. (Eds.), First International Conference on Groundwater Ecology. America Water Resources Association, Bethesda, MD, p. 133-142.

Romimohtarto, K. \& S. Juwana. 2001. Biologi laut: ilmu pengetahuan tentang biota laut. Jakarta. Penerbit Djambatan, 482 pp.

Sun, S. \& G.T. Zhang. 2005. Over summering strategy of Calanus sinicus. Global change newsletter no. 62 june, 2005 www.ntou.edu.tw/imb/download/seminar/20060329seminarl (Dilihat tanggal 10 Juni 2007).

Williamson, C.E. \&J.W. Reid. 2001. Ecology and classification of North American freshwater invertebrate. $2^{\text {nd }}$ Edition. Academic press, p. 915-954.

Yamaji, I. 1986. Ilustration of the marine plankton of Japan. Hoikusha Publishing. Co. Ltd, $537 \mathrm{pp}$. 